\title{
Hormonal Treatments for Bipolar Disorder: A Review of the Literature
}

\author{
Tuong-Vi Nguyen, Nancy C. P. Low \\ Department of Psychiatry, McGill University, Montreal, Canada \\ Email: tuong.v.nguyen@mail.mcgill.ca
}

Received August 23, 2011; revised October 21, 2011; accepted December 21, 2011

\begin{abstract}
Hormonal therapies may play a role in the treatment of bipolar disorder. Preliminary evidence suggests that: 1) Tamoxifen has anti-manic properties; 2) Hormone replacement therapy represents a good augmentation strategy in treatment-resistant peri-menopausal depression; and 3) Certain oral contraceptives could prevent menstrual exacerbations of affective symptoms. Potential neurobiological mechanisms of the anti-manic effects of tamoxifen include the inhibition of protein kinase $\mathrm{C}$ in addition its anti-estrogenic effects. Estrogen is a serotonergic and adrenergic agonist as well as an agent promoting neurogenesis in the hippocampus through glutamatergic synaptic formation, which may be the basis of its antidepressant activity. Progesterone appears to decrease serotonergic and adrenergic tone and activity, while increasing $\mathrm{GABA}_{\mathrm{A}}$ receptor activation through its active metabolite allopregnanolone, which may be the basis of its anxiolytic, sedative, and potentially anti-manic properties. Although there is consistency between the evidence for clinical efficacy and neurobiological mechanisms of hormonal treatments, the current state of knowledge relies on studies with several methodological limitations. On the other hand, benefits of hormonal treatment include protection from osteoporosis and several gynecological cancers, as well as safe contraception in a population at-risk for unplanned pregnancy. Nonetheless, hormonal treatments should be reserved for treatment-resistant bipolar depression or mania, or when contra-indications to other psychotropic medications are present. Institution of regular monitoring for medical complications and drug-drug interactions are essential to minimize risks and maximize benefits.
\end{abstract}

Keywords: Tamoxifen; Hormone Replacement Therapy; Oral Contraceptives; Mood; Mania; Depression

\section{Introduction}

Reproductive hormones appear to impact the course of bipolar disorder in women, particularly in the premenstrual, post-partum and perimenopausal phases [1-3]. Manic and depressive symptoms have been found to occur more frequently during the premenstrual (late luteal) phase; post-partum mood episodes were found to occur in $67 \%$ of bipolar mothers; and a significant proportion of bipolar women have reported a worsening of mood symptoms, primarily depressive, in the peri- and/or post-menopausal period [3]. Interestingly, tamoxifen, a known anti-cancer hormonal agent, was recently listed as a third-line option in the acute treatment of mania in the Canadian Network for Mood and Anxiety Treatments (CANMAT) guidelines, based on evidence of efficacy in recent trials with a purported mechanism of action similar to that of lithium and valproate $[4,5]$. In addition, the World Federation of Societies of Biological Psychiatry (WFSBP) rated the evidence for the anti-manic effect of tamoxifen as a category $\mathrm{B}$ and gave it a recommendation grade of 3 , just below the grade given to carbamazepine and olanzapine [6]. This raises questions regarding the role of hormonal treatments such as: 1) tamoxifen; 2) hormone replacement therapy (HRT); and 3) oral contraceptives (OCs) in the treatment of bipolar disorder, as preliminary evidence suggests these agents may possess mood stabilizing properties, primarily in terms of efficacy in: 1) acute mania; 2) acute depression; or 3) prevention of mood fluctuations across the menstrual cycle. Clinical interest in hormonal treatments first stemmed from studies in samples treated for other medical, non-psychiatric conditions. Unexpected effects of these treatments on mood came to light through these studies in women and men with no psychiatric history.

\subsection{Tamoxifen}

Tamoxifen is a selective estrogen receptor modulator, and acts as an estrogen agonist at some sites and an estrogen antagonist at other sites, such as breast tissue $[7,8]$. However, its effect in the central nervous system appears more complex, with possible agonist effects in some areas of the brain and antagonist effects in others [9]. Tamoxifen is commonly used as an adjuvant for the prevention of breast cancer recurrence in high-risk women and 
the treatment of estrogen-receptor positive breast cancer in post-menopausal women and metastatic estrogen-receptor positive breast cancer in both men and women [7]. Yet despite several years of tamoxifen use in non-psychiatric populations, its effect on mood remains uncertain. In addition to the new use of tamoxifen in mania, several case reports have reported tamoxifen-induced depression symptoms in breast cancer patients, but a large placebocontrolled randomized trial and a retrospective cohort study in the same population found no difference between the tamoxifen and control groups in terms of depressive symptoms [10-12].

\subsection{Hormone Replacement Therapy}

HRT is prescribed for the short-term treatment of moderate to severe peri-/post-menopausal vasomotor symptoms [13-16]. There are few reports of adverse mood symptoms with HRT in samples with no psychiatric history. One case report described the induction of mania with HRT use (estrogen only for 3 weeks and estrogen/progesterone for one week every month) in one 85 year-old post-menopausal women with no prior history of bipolar disorder [17]. On the other hand, studies have consistently shown increased rates of depression in the perimenopausal/menopausal period, even in women with no prior history of depression [18,19]. Measures of follicle-stimulating hormone (FSH), luteinizing hormone [20] and estradiol in an 8-year prospective cohort study revealed that greater variability in estradiol and $\mathrm{FSH}$ at the time of menopause was associated with increased incidence of depressed mood and depression in women with no prior history of depression [19].

\subsection{Oral Contraceptives}

In addition to being used for regular contraception, oral contraceptives (OCs) are also prescribed to relieve acne, dysmenorrhea, premenstrual dysphoric disorder, endometriosis, menorrhagia, uterine leiomyomas, pelvic inflammatory disease, and to regulate the menstrual cycle in women suffering from polycystic ovarian syndrome [21, $22]$. In samples of women with no current/prior psychiatric history, studies of OCs yielded mixed results, with older studies finding more adverse mood effects while more recent studies found some evidence of decreased mood fluctuations across the menstrual cycle [23-26]. This is thought to be due to changes in OCs formulation over time [23].

\section{Objectives}

Given the wide range of indications and prevalent use of hormonal treatments throughout the lifespan and recent findings on the potential novel use of tamoxifen in mania, it is timely to review the evidence of these treatments in bipolar disorder. The main objectives of this review are to: 1) summarize the current evidence for potential mood stabilization effects of tamoxifen, hormone replacement therapy and oral contraceptives; 2) review theoretical neurobiological mechanisms of hormonal treatments in bipolar disorder; and 3) discuss the medical benefits, adverse effects and pharmacological interactions of hormonal treatments with mainstay bipolar treatment (mood stabilizers, antipsychotics, antidepressants).

\section{Methods}

A literature search was conducted through EMBASE and MEDLINE from 1980 to 2010. This time period was chosen because hormonal replacement therapy received its first clinical indication for osteoporosis in the 1980s [27]. The following terms were used for the literature search: "tamoxifen", "hormone replacement therapy", "oral contraceptives", "bipolar disorder", "depression", "mania", "mood stabilizers", "antidepressants", "antidepressive agents", "anticonvulsants", "lithium", "antipsychotic agents", and "side effects". Manual literature searches based on bibliographies of relevant articles were also conducted. The main search using the terms "tamoxifen", "hormone replacement therapy", and "oral contraceptives" combined with "bipolar disorder", yielded 12 studies for tamoxifen, 12 studies for HRT, 14 studies for OCs through MEDLINE; the same search through EMBASE yielded 60 studies for tamoxifen, 30 studies for HRT and 124 studies for OCs. After careful review of the abstracts and elimination of duplicate studies, 25 studies were retained for review. Randomized controlled trials and non-randomized prospective clinical trials pertaining to hormonal treatments in bipolar disorder were prioritized. When such studies were not available or were few in number, observational studies, reviews and case reports of bipolar subjects were included.

\section{Results}

\subsection{Evidence of Mood Stabilization}

\subsubsection{Tamoxifen in Women and Men with Bipolar Disorder}

As detailed in Table 1, several studies demonstrate the anti-manic properties of tamoxifen in bipolar disorder, as adjunctive or monotherapy. Two 3-week randomized, double-blind placebo-controlled (RCTs) monotherapy trials of 66 and 16 bipolar subjects found an anti-manic effect of tamoxifen [28,29]. However, worsening of the placebo groups in both trials over the course of the study partially accounted for treatment differences. This calls into question the generalizability of these two RCTs, as worsening of the placebo group is not typical of trials targeting mania $[28,29]$. In a non-randomized, doubleblind, placebo- controlled 4-week study involving 13 wo- 
men, Kulkarni et al. observed a significant decrease in both manic and psychotic symptoms in the tamoxifen group [30]. In this study, tamoxifen or placebo were added to an ongoing regimen of lithium and/or valproic acid [30]. Finally, in a non-randomized, single-blind study of 7 subjects, Beb- chuck et al. observed a significant decrease in Youth Mania Rating Scale (YMRS) ratings [31]. Two of these patients were on other psychotropic agents [31]. Of note, no randomized controlled trials to date have shown a worsening or improvement of depresssive symptoms in bipolar patients associated with the use of tamoxifen [5].

\subsubsection{Hormone Replacement Therapy in Women with Bipolar Disorder}

As detailed in Table 2, there are few controlled studies assessing the mood stabilizing (predominantly antidepressant) effect of hormone replacement therapy in bipo- lar patients. In a prospective observational study of 170 depressed unipolar and bipolar post-menopausal women, HRT use was associated with significantly greater response to a selective serotonin reuptake inhibitor $(83.7 \%$. vs. $63.2 \%$ for non-HRT users) [32]. No significant differences were observed between estrogen-only and estrogen-progesterone users; surprisingly, there were also no significant differences in response between unipolar and bipolar populations [32]. In a retrospective study of 22 bipolar women, non-HRT users were significantly more likely than HRT users to report worsening in mood symptoms in the perimenopause/menopause period [1]. Chouinard et al. reported on 2 case reports of women in their 50s with treatment-resistant bipolar disorder, mainly consisting of depressive/mixed symptoms, who responded to a combination of estrogen and progesterone, while estrogen alone induced mania in one of these women [33]. In another case report, this time involving a

Table 1. Summary of studies examining the mood stabilizing effect of tamoxifen in bipolar disorder.

\begin{tabular}{|c|c|c|c|c|}
\hline STUDY & Yildiz et al. [28] & Zarate et al. [29] & Kulkarni et al. [30] & Bebchuck et al. [31] \\
\hline DESIGN & $\begin{array}{l}\text { Randomized } \\
\text { Double-blind } \\
\text { Placebo-controlled } \\
\text { Duration: } 3 \text { weeks }\end{array}$ & $\begin{array}{l}\text { Randomized } \\
\text { Double-blind } \\
\text { Placebo-controlled } \\
\text { Duration: } 3 \text { weeks }\end{array}$ & $\begin{array}{l}\text { No } \\
\text { randomization } \\
\text { Double-blind } \\
3 \text { arm-study: placebo, MPA }{ }^{\text {q斤 }} \text {, } \\
\text { tamoxifen } \\
\text { Duration: } 4 \text { weeks }\end{array}$ & $\begin{array}{l}\text { No randomization } \\
\text { Single-blind raters } \\
\text { Duration: mean } 8.4 \text { days }\end{array}$ \\
\hline SAMPLE & $\begin{array}{l}\mathrm{N}=66 \\
32 \text { males, } 34 \text { females } \\
\text { Inclusion: } \\
18 \text { - } 60 \text { yo with bipolar disor- } \\
\text { der on SCID } \\
\text { YMRS } ₫ 20 \\
\text { Exclusion: } \\
\text { Psychiatric comorbidities } \\
\text { Coagulopathies } \\
\text { Drop-out: } \mathrm{n}=6(17 \%) \text { of } \\
\text { tamoxifen, } \mathrm{n}=10(32 \%) \text { of } \\
\text { placebo }\end{array}$ & $\begin{array}{l}\mathrm{N}=16 \\
14 \text { males, } 2 \text { females } \\
\text { Inclusion: } \\
18 \text { - } 65 \text { yo with bipolar disor- } \\
\text { der on SCID-P** } \\
\text { YMRS }^{\S} \geq 14 \\
\text { Pre-menopausal } \\
\text { Exclusion: } \\
\text { Treatment-naïve } \\
\text { Substance use } \\
\text { disorders } \\
\text { Coagulopathies } \\
\text { Post-menopausal } \\
\text { Drop-out: } \mathrm{n}=4(50 \%) \text { of } \\
\text { tamoxifen, } \mathrm{n}=3(37 \%) \text { of } \\
\text { placebo }\end{array}$ & $\begin{array}{l}\mathrm{N}=13 \\
0 \text { males, } 13 \text { females } \\
\text { Inclusion: } \\
\text { Women with bipolar disorder } \\
\text { CARS-M } \mathrm{M}^{\uparrow} \geq 15 \\
\text { Follicular or luteal phase } \\
\text { Exclusion: } \\
\mathrm{N} / \mathrm{A} \\
\text { Drop-out: N/A }\end{array}$ & $\begin{array}{l}\mathrm{N}=7 \\
5 \text { males, } 2 \text { females } \\
\text { Inclusion: } \\
18 \text { - } 65 \text { yo with bipolar disor- } \\
\text { der on SCID** } \\
\text { YMRS }^{\S} \geq 14 \\
\text { Exclusion: } \\
\text { Psychiatric comorbidities } \\
\text { Coagulopathies } \\
\text { Drop-out: N/A }\end{array}$ \\
\hline $\begin{array}{l}\text { HORMONAL } \\
\text { TREATMENT }\end{array}$ & $\begin{array}{l}\text { Tamoxifen: } 80 \mathrm{mg} \text { po twice } \\
\text { daily } \\
\text { Placebo } \\
\text { Monotherapy } \\
\text { Lorazepam max. } 5 \mathrm{mg} \text { daily } \\
\text { given concomitantly }\end{array}$ & $\begin{array}{l}\text { Tamoxifen: } 20 \text { - } 140 \mathrm{mg} \text { daily } \\
\text { Placebo } \\
\text { Monotherapy } \\
\text { Lorazepam max. } 2 \mathrm{mg} \text { daily } \\
\text { given concomitantly }\end{array}$ & $\begin{array}{l}\text { Tamoxifen: } 40 \mathrm{mg} \text { daily } \\
\text { MPA }^{\uparrow \uparrow}: 20 \mathrm{mg} \text { daily } \\
\text { Placebo } \\
\text { Add-on to lithium \&/or valproate } \\
\text { for all subjects } n=13\end{array}$ & $\begin{array}{l}\text { Tamoxifen: } 80 \mathrm{mg} \text { po twice } \\
\text { daily } \\
\text { Add-on } \mathrm{n}=2 \\
\text { Monotherapy } \mathrm{n}=5\end{array}$ \\
\hline $\begin{array}{l}\text { OUTCOME } \\
\text { vs. baseline }\end{array}$ & $\begin{array}{l}\text { Change in } \mathrm{YMRS}^{\S} \geq 50 \% \text { : } \\
\text { Tamoxifen: } \\
\mathrm{N}=17(48 \%)^{*} \\
\text { Control: } \\
\mathrm{N}=2(5 \%)\end{array}$ & $\begin{array}{l}\text { Change in } \mathrm{YMRS}^{\S} \geq 50 \% \text { : } \\
\text { Tamoxifen: } \\
\mathrm{N}=5(63 \%)^{*} \\
\text { Control: } \\
\mathrm{N}=1(13 \%)\end{array}$ & $\begin{array}{l}\text { Change in mean CARS-M }{ }^{\uparrow} \text { : } \\
\text { Tamoxifen: }-22.2^{*} \\
\text { MPA }^{\uparrow \uparrow}:-13.0^{*} \\
\text { Control: }-8.5\end{array}$ & $\begin{array}{l}\text { Change in } \mathrm{YMRS}^{\S} \geq 50 \% \text { : } \\
\text { Tamoxifen: } \\
\mathrm{N}=5(71 \%)^{*} \\
\text { No control }\end{array}$ \\
\hline & NNT: 2.3 & NNT: N/A & NNT: N/A & NNT: N/A \\
\hline
\end{tabular}

*Significant differences vs. baseline or control group, $\mathrm{p}<0.05 ;{ }^{* *}$ SCID Structured Clinical Interview for DSM-IV or SCID-P Structured Clinical Interview for

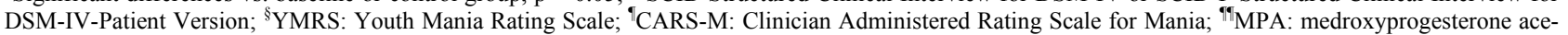
tate; NNT: number needed to treat; N/A: not available/specified. 
Table 2. Summary of studies examining the mood stabilizing effect of hormonal replacement therapy in bipolar disorder.

\begin{tabular}{|c|c|c|c|c|}
\hline STUDY & Zanardi et al. [32] & Freeman et al. [1] & Chouinard et al. [33] & Huang et al. [34] \\
\hline DESIGN & $\begin{array}{l}\text { Prospective } \\
\text { Observational } \\
\text { Combined treatment with HRT } \\
\text { and SSRIs } \\
\text { Duration: } 7 \text { weeks }\end{array}$ & $\begin{array}{l}\text { Retrospective } \\
\text { Observational } \\
\text { Duration: lifetime history of mood } \\
\text { symptoms }\end{array}$ & 2 case reports & 1 case report \\
\hline SAMPLE & $\begin{array}{l}\mathrm{N}=170 \\
170 \text { females } \\
57 \mathrm{HRT}^{\uparrow} \text { users } \\
123 \text { non-HRT } \\
\text { Inclusion: } \\
\geq 40 \text { yo, unipolar depression } \\
\mathrm{n}=134 \text { or bipolar disorder } \\
\mathrm{n}=36 \\
\mathrm{HAM}-\mathrm{D} 21^{\dagger} \geq 18 \\
\text { Post-menopausal } \\
\text { Exclusion: } \\
\text { Psychiatric comorbidities } \\
\text { Severe physical illness } \\
\text { Drop-out: } \mathrm{n}=13(8 \%) \text { in the whole } \\
\text { sample, secondary to adverse effects } \\
\text { from SSRIs }\end{array}$ & $\begin{array}{l}\mathrm{N}=22 \\
22 \text { females } \\
12 \text { current } \mathrm{HRT}^{\Uparrow} \text { users } \\
2 \text { past } \mathrm{HRT}^{\pi} \text { users } \\
8 \text { non-HRT } \mathrm{HR}^{\Uparrow} \text { users } \\
\text { Inclusion: } \\
\text { Mean age } 43.3+/-11.4 \text { yo with } \\
\text { bipolar disorder on SCID** } \\
\text { Exclusion: Nil } \\
\text { Drop-out: } \mathrm{n}=2 \text { (9\%) stopped HRT } \\
\text { secondary to adverse effects of HRT }\end{array}$ & $\begin{array}{l}\mathrm{N}=2 \\
2 \text { females } \\
2 \text { cases of bipolar disorder } \\
\text { resistant to lithium } \\
1 \text { post-menopausal } \\
\text { women }\end{array}$ & $\begin{array}{l}\mathrm{N}=1 \\
1 \text { female } \\
\text { History of bipolar } \\
\text { disorder } \\
1 \text { post-partum } \\
\text { woman, mania } \\
\text { resistant to lithium, } \\
\text { valproate, } \\
\text { antipsychotics }\end{array}$ \\
\hline $\begin{array}{l}\text { HORMONAL } \\
\text { TREATMENT }\end{array}$ & $\begin{array}{l}\text { HRT }^{\uparrow} \text { : } \\
-66 \% \text { on conjugated estrogens } \\
\text { (mean dose } 0.611 \mathrm{mg} \text { ) and } \\
\text { medroxyprogesterone } \\
(10-12 \text { days per month; } \\
\text { mean dose } 5 \mathrm{mg} \text { ) } \\
-34 \% \text { on estrogens alone } \\
\text { (mean dose } 0.689 \mathrm{mg} \text { ) } \\
\text { SSRIs } \text { : All subjects received } \\
\text { SSRIs at usual doses: sertraline, } \\
\text { paroxetine, citalopram, fluoxetine }\end{array}$ & $\begin{array}{l}\text { HRT }^{\%} \text { : } \\
-50 \% \text { on estrogens \& progesterone } \\
\text { (estradiol + methylprogesterone OR } \\
\text { conjugated estrogens }+ \\
\text { medroxyprogesterone) } \\
-42 \% \text { on estradiol alone } \\
-8 \% \text { on medroxyprogesterone } \\
\text { alone }\end{array}$ & 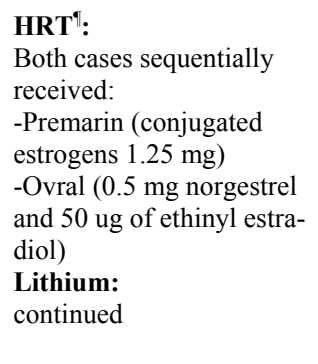 & $\begin{array}{l}\text { HRT": } \\
\text { Conjugated } \\
\text { estrogen ( } 0.625 \\
\text { mg/day) and me- } \\
\text { droxyprogesterone } \\
\text { ( } 2.5 \mathrm{mg} / \text { day) } \\
\text { Lithium \& } \\
\text { valproate: } \\
\text { continued }\end{array}$ \\
\hline $\begin{array}{l}\text { OUTCOME } \\
\text { vs. baseline }\end{array}$ & 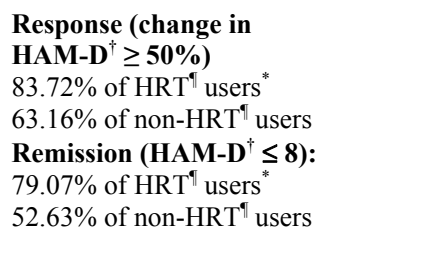 & $\begin{array}{l}\text { No change in mood symptoms } \\
\text { at perimenopause: } \\
75 \% \text { of } \mathrm{HRT}^{\oplus} \text { users" } \\
12 \% \text { of non-HRT }{ }^{*} \text { users } \\
\text { Worsening of mood symptoms } \\
\text { at perimenopause/menopause: } \\
25 \% \text { of } \mathrm{HRT}^{*} \text { users* } \\
88 \% \text { of non-HRT }{ }^{*} \text { users }\end{array}$ & $\begin{array}{l}\text { Remission } \\
\text { according to DSM-IV } \\
\text { criteria: } \\
\text { Both cases remitted. } \\
\text { Premarin precipitated } \\
\text { mania in 1 patient, Ovral } \\
\text { had antidepressant and } \\
\text { mood stabilizing properties }\end{array}$ & $\begin{array}{l}\text { Remission accord- } \\
\text { ing to DSM-IV } \\
\text { criteria }\end{array}$ \\
\hline
\end{tabular}

*Significant differences vs. baseline or control group, $\mathrm{p}<0.05 ;{ }^{* *}$ SCID Structured Clinical Interview for DSM-IV; $\uparrow$ HRT: hormonal replacement therapy; ${ }^{\S}$ SSRI: selective serotonin reuptake inhibitor; ${ }^{\dagger} H A M-D$ 21: 21-item Hamilton Depression Scale; N/A: not available/specified.

treatment-resistant post-partum mania, Huang et al. reported the effectiveness of HRT in combination with lithium and valproic acid [34]. The patient remained in remission after the withdrawal of HRT 2 months after treatment initiation [34].

\subsubsection{Oral Contraceptives in Women with Bipolar Disorder}

To our knowledge, there is one only study to date in bipolar subjects examining the mood stabilizing effects of oral contraceptives. In a non-randomized sample of women with bipolar disorder, Rasgon et al. observed 17 subjects (6 OC users, 11 non-OC users) over the course of 3 months and found less mood variability/fluctuations across the menstrual cycle in OC users [35]. Bias due to self- selection into the OC group and continuation of other medications such as mood stabilizers and antidepressants over the course of the study constitute significant limitations [35].

\subsection{Potential Neurobiological Mechanisms Underlying Mood Stabilizing Effects}

\subsubsection{Tamoxifen}

Tamoxifen is a selective protein kinase $\mathrm{C}$ inhibitor as well as a partial estrogen antagonist, with agonist properties in endometrial tissue and antagonist properties in breast tissue [7,8]. However, its effects on the central nervous system appear are complex: it appears to act as a serotonergic antagonist, while promoting cholinergic and 
adrenergic activity $[9,36]$.

Tamoxifen trials were initiated in manic subjects on the basis of its inhibition of protein kinase C (PKC), a mechanism that is also thought to be partially responsible for the mood stabilizing properties of lithium and valproic acid [5]. Unfortunately, preliminary studies of tamoxifen in humans were not adequately powered or methodologically designed to distinguish the effect of PKC inhibition of tamoxifen from its effect on estrogen [5]. The only head-to-head study of tamoxifen with the anti-estrogen agent medroxyprogesterone in humans did not find significant differences between these medications in terms of their anti-manic effect [30]. One animal study using an amphetamine-induced manic model in mice found a greater anti-manic effect of lithium, tamoxifen or chelerythrine (a selective PKC inhibitor) monotherapy when compared to medroxyprogesterone, suggesting that the anti-manic effect of tamoxifen is distinct from its anti-estrogen effect [37]. Of note, both animal and human studies were either not adequately powered to control for sex or have not shown any difference between sexes in response to tamoxifen [28-31,37].

\subsubsection{Hormone Replacement Therapy and Oral Contraceptives}

Evidence from RCTs in depressed peri- and post-menopausal women suggest that mood disorders in the perimenopausal phase are due to hormonal changes (acute withdrawal or fluctuations) in the early perimenopausal period rather than chronic hormone-deficient states in women who have been post-menopausal for more than 510 years [18]. Therefore, the primary aim of hormone replacement therapy is to stabilize hormonal levels in perimenopausal women.

Oral contraceptives are also thought to result in more stable levels of hormones throughout the menstrual cycle [25]. This is relevant in women with bipolar disorder, as they not only commonly experience an exacerbation of their affective symptoms in the late luteal phase, but also appear to show greater hormonal fluctuations across the menstrual cycle, a difference that remains significant after controlling for comorbidities and treatment effects [38].

Estrogen appears to have widespread effects in the brain, and it has been noted to act on serotonergic, adrenergic, dopaminergic, and basal forebrain cholinergic pathways $[9,39,40,42,43]$. It has also been found to be implicated in the formation of new NMDA synapses in the CA1 region of the hippocampus, possibly potentiating long-term memory but also decreasing seizure threshold [9]. Among the various neurotransmitters, the relationship between estrogen and the serotonergic system has been most thoroughly studied, and in this case, may relate directly to its antidepressant effect. These effects are complex: estrogen appears to increase genomic expression of tryptophan hydroxylase and decrease the activity of monoamine oxidase in animal studies, potentially leading to increased serotonin synthesis $[9,41,44]$; it has also been found to increase the activity of the serotonin transporter gene, leading to increased serotonin turnover [44]. In addition, estrogen appears to increase the sensitivity of post-synaptic 5-HT1a receptors and to decrease the sensitivity of pre-synaptic 5-HT1a autoreceptors [44]. There have also been reports of estrogen-related increases in density of post-synaptic 5-HT2a receptors in the amygdala, hippocampus, nucleus accumbens and a number of cortical areas [9]. These various neuronbiological changes seem to lead overall to an increase in serotonergic activity and turnover, while a decrease in serotonergic tone and activity, associated with increased pre-synaptic 5-HT1a autoreceptor binding, has been reported in bipolar depression [45]. In addition, estrogen appears to increase norepinephrine turnover and decrease norepinephrine reuptake, though this is not as well documented than the effects on the serotonergic system [9]. Both serotonergic and adrenergic effects could therefore underlie estrogen's antidepressant effect, as well as the less common, but reported induction of mania with the administration of estrogen $[1,17,32,33]$. Other effects of estrogen, such as a possible antidopaminergic effect by blocking D2 receptors, similar to the mechanism of action of antipsychotics, or the increase in frontal release of acetylcholine and decreased catabolism of this neurontransmitter, may be associated with other beneficial psychotropic effects of estrogen, but direct implications with regards to bipolar depression and mania are not evident.

In contrast to estrogen, progesterone appears to decrease 5-HT1a binding potential and to downregulate the formation of NMDA synapses in the hippocampus [9,39]. In addition, progesterone seems to mainly act on the central nervous system through one of its metabolites, allopregnanolone, and its agonistic effects on $\mathrm{GABA}_{\mathrm{A}}$ receptors [46]. Progesterone also decreases the activity of nicotinic cholinergic receptors, and reduces noradrenergic tone by decreasing receptor sigma-1 activity as well as increasing catabolism of this neurotransmitter [42]. Thus it is believed to have anxiolytic and sedating effects, though depressogenic and adverse cognitive effects have also been reported $[9,39,42,46]$. On the other hand, effects on the dopaminergic system are complex, differing depending on the regions of the cortex or subcortical structures, and are not clearly associated with bipolar depression or mania [42].

It appears that estrogen and progesterone act, at least partly, on the same neurotransmitter systems, though in a mostly antagonistic manner $[9,39,42]$. This interaction is complex, as estrogen also increases the expression of progesterone receptors $[9,39]$. Nonetheless, it appears that estrogen has potential antidepressant effects, while pro- 
gesterone appears to have depressogenic and anxiolytic effects [9]. The combination of both estrogen and progesterone could therefore have mood stabilizing properties. Few studies have been designed to answer this question. Kurshan et al. report that combining estrogen and progesterone reduces levels of dehydroepiandrosterone-sulfate (DHEAS), a $\mathrm{GABA}_{\mathrm{A}}$ receptor antagonist [46]. This effect has been hypothesized to be partly responsible for the mood stabilizing effect of estrogen-progesterone combinations, but these considerations remain speculative [46].

\subsection{Medical Benefits, Adverse Effects and Pharmacological Interactions}

Table 3 summarizes advantages, adverse effects and drug interactions of tamoxifen, hormonal replacement therapy and oral contraceptives.

\subsubsection{Tamoxifen}

In addition to its use in breast cancer, benefits associated with tamoxifen use include a bone-sparing effect comparable to that of raloxifene, a selective estrogen receptor modulator used in the treatment of osteoporosis [49], the absence of metabolic side-effects such as weight gain, diabetes, hyperlipidemia and of neurological side-effects such as extra-pyramidal symptoms and tremors, in contrast to antipsychotics often used in the treatment of acute mania. On the other hand, tamoxifen is commonly associated with side-effects related to its antiestrogenic effect: hot flashes, vaginal discharge, irregular menstrual periods, headaches, fatigue, nausea and/or vomiting, vaginal dryness or itching, irritation of the skin around the vagina, and skin rash [47]. It is also known to have teratogenic effects on the fetus [47]. Men who take tamoxifen may experience headaches, nausea and/or vomiting, skin rash, impotence, or a decrease in sexual interest [47]. Other

Table 3. Summary of hormonal treatments: advantages, adverse effects, drug interactions.

\begin{tabular}{|c|c|c|c|}
\hline & Advantages & Adverse effects & Drug interactions \\
\hline Tamoxifen & $\begin{array}{l}\text { Rapid onset of action, can be added to } \\
\text { benzodiazepines or lithium/valproate in } \\
\text { patients with contra-indication to } \\
\text { antipsychotics } \\
\text { No metabolic side-effects such as } \\
\text { weight gain, diabetes, hyperlipidemia }\end{array}$ & $\begin{array}{l}\text { Common antiestrogenic side-effects: } \\
\text { Hot flashes, vaginal discharge, } \\
\text { irregular menstrual periods, } \\
\text { headaches, fatigue, nausea, and/or } \\
\text { vomiting, skin rash, decreased libido } \\
\text { Teratogenic effects on the fetus }\end{array}$ & $\begin{array}{l}\text { Selective serotonin reuptake } \\
\text { inhibitors (particularly paroxetine, } \\
\text { fluoxetine, fluvoxamine): } \\
\text { decrease levels of the active } \\
\text { metabolite of tamoxifen, } \\
\text { hydroxytamoxifen, therefore leads } \\
\text { to decreased efficacy }\end{array}$ \\
\hline & $\begin{array}{l}\text { No neurological side-effects such as } \\
\text { extra-pyramidal symptoms, tremors } \\
\text { Bone-sparing effect protecting against } \\
\text { osteoporosis }\end{array}$ & $\begin{array}{l}\text { Rare side-effects: endometrial } \\
\text { carcinoma, thromboembolism, } \\
\text { cataracts }\end{array}$ & $\begin{array}{l}\text { Valproic acid: may also decrease } \\
\text { levels of hydroxytamoxifen }\end{array}$ \\
\hline $\begin{array}{l}\text { Hormone replacement } \\
\text { therapy (HRT) }\end{array}$ & $\begin{array}{l}\text { May be used an an add-on to } \\
\text { antidepressants in treatment-resistant } \\
\text { perimenopausal depression }\end{array}$ & $\begin{array}{l}\text { Coronary artery disease: risk can be } \\
\text { minimized by limiting use to } 5-10 \\
\text { years around the time of menopause }\end{array}$ & $\begin{array}{l}\text { Anticonvulsants: HRT may } \\
\text { decrease seizure threshold } \\
\text { (mainly an effect of estrogen) }\end{array}$ \\
\hline & $\begin{array}{l}\text { Benefits for other perimenopausal } \\
\text { symptoms: decreasing vasomotor } \\
\text { symptoms, increasing vaginal } \\
\text { lubrication and decreasing urogenital } \\
\text { atrophy, decreasing arthralgia, } \\
\text { protecting against osteoporosis and } \\
\text { colorectal cancer }\end{array}$ & $\begin{array}{l}\text { Thromboembolism: risk can be } \\
\text { minimized with the use of a } \\
\text { transdermal patch } \\
\text { Minimal increase in stroke and } \\
\text { breast cancer: can be minimized by } \\
\text { screening for risk factors }\end{array}$ & $\begin{array}{l}\text { Lamotrigine: levels may be } \\
\text { decreased by HRT } \\
\text { Clozapine: levels may be } \\
\text { increased by HRT }\end{array}$ \\
\hline $\begin{array}{c}\text { Oral } \\
\text { contraceptives (OCs) }\end{array}$ & $\begin{array}{l}\text { May be used to decrease menstrual } \\
\text { exacerbations of affective symptoms } \\
\text { and treat comorbid premenstrual } \\
\text { dysphoric disorder (especially } \\
\text { formulations containing drospirenone) } \\
\text { Contraception } \\
\text { Reduction of dysmenorrhea, } \\
\text { menorrhagia, acne, endometriosis, } \\
\text { uterine leiomyomas, pelvic } \\
\text { inflammatory disease, ovarian, } \\
\text { endometrial, colorectal cancer }\end{array}$ & $\begin{array}{l}\text { Common side-effects: bloating, } \\
\text { breast tenderness, migraine, nausea } \\
\text { and acne } \\
\text { Rare side-effects (can be minimized } \\
\text { by using OCs with lower } \\
\text { estrogen/progesterone content): } \\
\text { hyperlipidemia, hypertension, } \\
\text { thromboembolic disorder ( }>35 \text { yo } \\
\text { female + smoking) }\end{array}$ & $\begin{array}{l}\text { Enzyme-inducing anticonvulsants } \\
\text { (carbamazepine, phenytoin, } \\
\text { phenobarbital): decrease levels of } \\
\text { OCs } \\
\text { Lamotrigine: levels are decreased } \\
\text { by OCs } \\
\text { Clozapine: levels are increased by } \\
\text { OCs }\end{array}$ \\
\hline
\end{tabular}


less common, but serious medical complications associated with tamoxifen include endometrial carcinoma, thromboembolism and cataracts $[47,48]$. Its use is associated with a 2 to 7 fold increased risk of endometrial carcinoma, which increases with duration of use, though the absolute risk remains low at $0.02 \%$ [47,48]. In terms of drug-drug interactions, most studies on tamoxifen and antidepressants have involved women with breast cancer. There is a potential interaction between tamoxifen and selective serotonin reuptake inhibitors (SSRIs), particularly fluoxetine, paroxetine and sertraline as well as the serotonin-noradrenaline reuptake inhibitor (SNRI) duloxetine and the noradrenaline-dopamine reuptake inhibitor (NDRI) bupropion, because they inhibit cytochrome p450 2D6, preventing metabolism of tamoxifen to its active antiestrogenic metabolite, hydroxytamoxifen [7]. On the other hand, cohort and case-control studies of breast cancer patients question the clinical significance of this interaction $[50,51]$. With respect to tamoxifen and interactions with mood stabilizers, valproic acid (a known inhibitor of p450 enzymes) could decrease the levels of hydroxytamoxifen, although this has not been formally studied. In terms of enzyme-inducing mood stabilizers such as carbamazepine, animal studies report that tamoxifen appears to potentiate the anticonvulsive effect of phenytoin and carbamazepine resulting in lower dose requirements for these anticonvulsants, possibly through competition for the metabolizing p450 enzymes [52]. Human studies are lacking. To our knowledge, there is no evidence of an interaction between lithium and tamoxifen, and studies are needed on the subject. With respect to interactions between tamoxifen and antipsychotics, there is no conclusive evidence in humans. One case series reported successful treatment of tamoxifen-induced insomnia with quetiapine, with no noticeable interaction [53], while one animal study showed a synergistic effect of chlorpromazine and tamoxifen in terms of its anti-estrogen effect [54].

\subsubsection{Hormone Replacement Therapy}

Benefits associated with the use of hormone replacement therapy in perimenopausal women include the decrease of vasomotor symptoms (hot flushes), improvement of arthralgia and other somatic complaints, increase in vaginal lubrication and decrease in urogenital atrophy, prevention of osteoporosis and decreased risk in colorectal and endometrial cancer [13].

Medical complications of HRT include a potential increase in risk of coronary heart disease (though controversial), and minimal increase in risk of stroke, breast cancer and thromboembolism [13]. Of note, some of the risks of HRT, notably coronary artery disease and thromboembolism, can be minimized either with initiation of therapy within 10 years of menopause or the use of a transdermal patch, respectively $[55,56]$. HRT continues to be commonly prescribed in the short-term treatment of moderate to severe peri- and/or post-menopausal vasomotor symptoms [14-16]. Drug-drug interactions studies conducted between HRT and mood stabilizers involve mainly women with epilepsy. A randomized, doubleblind, controlled study in epileptic women $(n=21)$ found a dose-related increase in seizure frequency in HRT users, despite the use of appropriate anticonvulsant drugs [57]. Estrogen may act directly on brain activity, increasing glutamatergic activity and reducing gabaergic activity, leading to a decrease in seizure threshold [58]. HRT also appears to decrease lamotrigine levels (see "Oral contraceptives" below) [57]. Otherwise, there is no conclusive evidence that HRT interacts significantly with lithium, antidepressants or antipsychotics, though the one case report of elevated levels of clozapine with OCs may also apply to HRT, as estrogen and progesterone doses are much higher in HRT and would likely have a greater effect on levels of clozapine compared to OCs (see "Oral contraceptives" below) [59].

\subsubsection{Oral Contraceptives}

In addition to evident contraceptive benefits, oral contraceptives appear to decrease acne, dysmenorrhea, menorrhagia, premenstrual dysphoric disorder, endometriosis, uterine leiomyomas, pelvic inflammatory disease, and to regulate the menstrual cycle in women suffering from polycystic ovarian syndrome. In addition, OCs also reduce the risk of ovarian cancer, endometrial and colorectal cancer, as well as possibly decreasing the risk of sexually transmitted diseases associated with a thickening of cervical mucus [22].

Common medical side effects of OCs include bloating, breast, tenderness, nausea and acne. More serious sideeffects include an increased risk of migraine, dyslipidemia, hypertension, and thromboembolic disorder, particularly if the patient smokes cigarettes and is over the age of 35 years [60]. However, more recent OC formulations with lower estrogen and progesterone content mitigate these more serious side-effects [60]. Drug-drug interaction studies conducted between OCs and mood stabilizers consist mainly of observational, open-labels trials and case reports, mainly of women with epilepsy and healthy volunteers [59,61-70]. The use of carbamazepine, an enzyme-inducing mood stabilizer, has been shown to be associated with higher failure rates of OCs, about twice that of the general population [61]. Although valproic acid could in theory be associated with elevated levels of estrogen and progesterone (through inhibition of cytochrome p450 enzymes), one observational study as well as one clinical trial conducted on epileptic populations have shown that this interaction does not result in significant alterations in hormonal levels, though rates of 
contraceptive failure were not assessed [62,63]. Oxcarbazepine, lamotrigine and topiramate the latter at doses higher than $200 \mathrm{mg}$ /day also induce the metabolism of oral contraceptives, though it is unclear if this effect is clinically significant [64-67]. On the other hand, serum lamotrigine levels were found to be decreased by concomitant use of OCs [64,68-70]. It is thought that estrogen stimulates the glucuronyl transferase enzyme involved in the metabolism of both ethinyl estradiol and lamotrigine [71]. There is no conclusive evidence that clinically significant interactions exist between OCs and 1) lithium 2) antidepressants or 3) antipsychotics. Only one case report described increased clozapine levels with mild adverse effects (drowsiness, weakness, and dizziness) associated with the use of an OC [59]. The mechanism is thought to be related to the inhibition of CYP3A4 by OCs, with possible additional effects on the activity of CYP1A2, CYP3A4, CYP2C19 [59].

\section{Discussion}

\subsection{Tamoxifen}

According to the current state of the evidence, tamoxifen appears to demonstrate short-term anti-manic properties in bipolar patients, both male and female, although longer-term, higher powered studies are needed before tamoxifen can be considered standard treatment. Design and other methodological limitations such as incorporation of the concomitant use of mood stabilizers (lithium, valproic acid) and tranquilizers/hypnotics (lorazepam) also affect the generalizability of the current studies [2830]. Rebound mania remains a concern with short-term treatment while long-term treatment brings adverse effects which may well be unacceptable for several patients [48]. On the other hand, potential medical benefits include bone-sparing effects and the absence of metabolic or neurologic side-effects common with antipsychotic medication, often used in the acute treatment period for mania. As per the CANMAT and the WFSBP guidelines, tamoxifen is a third-line option in treatmentresistant mania [72]. It should ideally be prescribed in conjunction with a family physician or gynecologist. In addition, treatment should be limited to the acute period [48]. Careful review of personal and family medical history for any endometrial/uterine neoplasms and coagulopathies/thromboembolic disease (blood clots, stroke) should be completed prior to initiation, using collateral sources if necessary. In addition, women taking this medication should use appropriate contraceptive methods due to teratogenic risks associated with tamoxifen [47]. Of note, there appears to be decreased efficacy of tamoxifen in terms of its anti-estrogen effect when it is prescribed concomitantly with certain SSRIs [50,51]. Tamoxifen may also increase levels of carbamazepine, and possibly other anticonvulsants used as mood stabilizers [57]. Monitoring of drug levels and appropriate adjustment of doses should be instituted.

\subsection{Hormone Replacement Therapy}

The two observational studies in bipolar subjects (one retrospective, the other prospective) showed evidence of mood stabilization effects of HRT $[1,32]$. Both the combination of estrogen and progesterone and estrogen alone appeared to alleviate depressive symptoms and augment antidepressant response in peri-/post-menopausal women [1,32]. Evidence from RCTs in depressed peri-/post-menopausal women suggest that mood disorders in the perimenopausal phase are due to hormonal changes (withdrawal, fluctuations) in the early perimenopausal period; as such, HRT may have a role in the treatment of depression in younger perimenopausal women less than 5 years post-menopause [18]. The availability of a transdermal hormonal patch, which is not associated with excess risk of thromboembolism, is an attractive option in non-compliant patients [55]. Medical indications for HRT use include treatment of vasomotor symptoms in peri- and post-menopausal women [14-16], and it also decreases other peri-menopausal symptoms (urogenital atrophy, decreased vaginal lubrication), in addition to protecting against osteoporosis and colorectal cancer [13]. However, HRT appears to reduce seizure threshold and to decrease levels of lamotrigine [57]. Adequate monitoring of levels of mood stabilizers with subsequent dose adjustments is recommended.

\subsection{Oral Contraceptives}

The only observational study of OCs in bipolar women showed evidence for mood stabilization, in terms of decreased mood fluctuations across the menstrual cycle [35]. Oral contraceptives may be used in certain subsets of treatment-resistant bipolar women, more specifically women with exacerbation of symptoms in the premenstrual period or with co-morbid premenstrual dysphoric disorder $[22,23,46,73,74]$. Two randomized controlled trials found that forms of OCs using newer progestins such as drospirenone (brand names: Yasmin, Yaz) appear beneficial in this population, though studies with other, older OCs have been inconsistent [22,23,46,73,76,77]. Monophasic OCs and a 24/4 regimen (with only 4-days OC-free) appear to correlate with greater mood stabilization and less adverse negative mood symptoms $[25,75]$. Of note, bipolar women of reproductive age may benefit from both the contraception and the mood stabilizing effect of OCs. This is particularly relevant as more than $40 \%$ of bipolar women do not use proper contraception [20]. Evidence about the mood stabilizing effect of OCs may contribute to better compliance in this regard. In terms of pharma- 
cological interactions, carbamazepine decreases OCs levels; in turn, OCs decrease lamotrigine levels $[61,68]$. When using concomitant enzyme-inducing anticonvulsants such as carbamazepine along with OCs, discussion with the patient about the incurred risk of contraceptive failure is essential. To counteract the interaction between OCs and lamotrigine, some studies have suggested increasing the dose of lamotrigine by up to 2-fold upon starting an OC, and reducing the dose by up to $50 \%$ upon discontinuation of an OC [61]. For women already on OCs, lamotrigine can be started as per the usual dosing regimen, and titrated accordingly [61].

\section{Conclusions}

More research on hormonal treatments for bipolar disorder is required to further elucidate and clarify the precise neurobiological mechanisms underlying their role in the treatment and course of bipolar disorder. However, as the number of studies in bipolar disorder accumulates on hormonal treatments, physicians need to be updated on the evidence for clinical indications, medical complications and pharmacological interactions associated with these medications. Subsets of treatment-resistant patients may benefit from adjunctive treatment with tamoxifen, HRT, or OCs. Thus close attention should be paid to patterns of mood fluctuations across the menstrual cycle, or change in symptoms when entering the perimenopausal period, as these may determine patients' suitability for hormonal treatments. A thorough pre-treatment medical and medication history is also important.

Future research on the etiology of disorder should focus on differentiating the effect of protein kinase $\mathrm{C}$ from the anti-estrogen effect of tamoxifen and on clarifying the mechanisms of action of estrogen and progesterone on the central nervous system. Establishing the means to evaluate the ideal estrogen and progesterone dose, for example through hormonal levels, and establishing the best method of delivery would likely optimize the efficacy of hormonal treatments. In addition, longer-term, prospective studies need to be completed with tamoxifen to determine its effect on manic symptoms beyond 4 weeks of treatment. Randomized controlled trials of bipolar subjects using HRT and OCs also need to be completed to secure their place in the hierarchy of standard treatment. For now, these treatments should be reserved for treatment-resistant bipolar patients or those with contraindications to standard treatments.

\section{REFERENCES}

[1] M. Freeman, S. Kmith, S. Freeman, S. McElroy, G. Kmetz, R. Wright and P. Keck, "The Impact of Reproductive Events on the Course of Bipolar Disorder in Women," Journal of Clinical Psychiatry, Vol. 68, 2002, pp.
284-287. doi:10.4088/JCP.v63n0403

[2] V. Burt and N. Rasgon, "Special Considerations in Treating Bipolar Disorder in Women," Bipolar Disorders, Vol. 6, No. 1, 2004, pp. 2-13. doi:10.1046/j.1399-5618.2003.00089.x

[3] S. McElroy, L. Arnold and L. Altshuler, "Bipolarity in Women: Therapeutic Issues," Bipolar Psychopharmacotherapy, 2006, pp. 235-277.

[4] L. Yatham, et al., "Canadian Network for Mood and Anxiety Treatments (CANMAT) and International Society for Bipolar Disorders (ISBD) Collaborative Update of CANMAT Guidelines for the Management of Patients with Bipolar Disorder: Update 2009," Bipolar Disorders, Vol. 11, No. 3, 2009, pp. 225-255. doi:10.1111/j.1399-5618.2009.00672.x

[5] N. DiazGranados, et al., "A Review of the Preclinical and Clinical Evidence for Protein Kinase C as a Target for Drug Development for Bipolar Disorder," Current Psychiatry Reports, Vol. 10, No. 6, 2008, pp. 510-519. doi:10.1007/s11920-008-0081-7

[6] H. Grunze, et al., "The World Federation of Societies of Biological Psychiatry (WFSBP) Guidelines for the Biological Treatment of Bipolar Disorders: Update 2009 on the Treatment of Acute Mania," The World Journal of Biological Psychiatry, Vol. 10, No. 2, 2009, pp. 85-116. doi:10.1080/15622970902823202

[7] J. Desmarais, et al., "Interactions between Tamoxifen and Antidepressants via Cytochrome p450 2d6," Journal of Clinical Psychiatry, Vol. 70, No. 12, 2009, pp. 1688-1697. doi:10.4088/JCP.08r04856blu

[8] J. Eberling, "Estrogen- and Tamoxifen-Associated Effects on Brain Structure and Function," NeuroImage, Vol. 2, No. 1, 2003, pp. 364-371.

doi:10.1016/j.neuroimage.2003.08.037

[9] B. McEwen, "Estrogen Actions throughout the Brain," The Endocrine Society, Vol. 57, No. 1, 2002, pp. 357-384.

[10] F. Bourque, et al., "Acute Tamoxifen-Induced Depression and Its Prevention with Venlafaxine," Psychosomatics, Vol. 50, No. 2, 2009, pp. 162-165. doi:10.1176/appi.psy.50.2.162

[11] K. Lee, et al., "Tamoxifen Treatment and New-Onset Depression in Breast Cancer Patients," Psychosomatics, Vol. 48, No. 3, 2007, pp. 205-210. doi:10.1176/appi.psy.48.3.205

[12] R. Day, et al., "Tamoxifen and Depression: More Evidence From the National Surgical Adjuvant Breast and Bowel Project's Breast Cancer Prevention (P-1) Randomized Study," Journal of the National Cancer Institute, Vol. 93, No. 21, 2001, pp. 1615-1623. doi:10.1093/jnci/93.21.1615

[13] Writing Group for the Women's Health Initiative Investigators, "Risks and Benefits of Estrogen plus Progestin in Healthy Postmenopausal Women Principal Results from the Women's Health Initiative Randomized Controlled Trial," The Journal of the American Medical Association, Vol. 288, No. 3, 2002, pp. 321-333.

[14] H. Nelson, et al., "Postmenopausal Hormone Replacement Therapy: Scientific Review," The Journal of the American Medical Association, Vol. 288, No. 7, 2002, pp. 
872-881. doi:10.1001/jama.288.7.872

[15] T. Kocjan, et al., "Hormone Replacement Therapy Update: Who Should We Be Prescribing This to Now?" Current Opinion in Obstetrics and Gynecology, Vol. 15, No. 6, 2003, pp. 459-464. doi:10.1097/00001703-200312000-00001

[16] N. Mikhail, et al., "Lessons Learned from the Women's Health Initiative Study," Southern Medical Journal, Vol. 96, No. 9, 2003, pp. 940-941. doi:10.1097/01.SMJ.0000086760.59141.BD

[17] R. Young, et al., "Hormone Replacement Therapy and Late-Life Mania," The American Journal of Geriatric Psychiatry, Vol. 5, No. 2, 1996, pp. 179-181.

[18] P. Schmidt, et al., "Sex Hormones and Mood in the Perimenopause," Annals of the New York Academy of Sciences, Vol. 1179, 2009, pp. 70-85. doi:10.1111/j.1749-6632.2009.04982.x

[19] E. Freeman, et al., "Associations of Hormones and Menopausal Status with Depressed Mood in Women with No History of Depression," Archives of General Psychiatry, Vol. 63, No. 4, 2006, pp. 375-382. doi:10.1001/archpsyc.63.4.375

[20] P. Magalhaes, et al., "Use of Contraceptive Methods among Women Treated for Bipolar Disorder," Archives of Women's Mental Health, Vol. 12, No. 3, 2009, pp. 183185. doi:10.1007/s00737-009-0060-y

[21] H. Van Vliet, et al., "Triphasic versus Monophasic Oral Contraceptives for Contraception for Cochrane (Reviews)," The Cochrane Collaboration, Oxford, 2006.

[22] J. Huber, et al., "Non-Contraceptive Benefits of Oral Contraceptives," Expert Opinion on Pharmacotherapy, Vol. 9, No. 13, 2008, pp. 2317-2325. doi:10.1517/14656566.9.13.2317

[23] K. Oinonen and D. Mazmanian, "To What Extent Do Oral Contraceptives Influence Mood and Affect?" Journal of Affective Disorders, Vol. 70, No. 3, 2002, pp. 229240. doi:10.1016/S0165-0327(01)00356-1

[24] J. Jarva and K. Oinonen, "Do Oral Contraceptives Act as Mood Stabilizers? Evidence of Positive Mood Stabilization," Archives of Women's Mental Health, Vol. 10, No. 5, 2006, pp. 225-234.

doi:10.1007/s00737-007-0197-5

[25] T. Greco, et al., "The Effects of Oral Contraceptives on Androgen Levels and Their Relevance to Premenstrual Mood and Sexual Interest: A Comparison of Two Triphasic Formulations Containing Norgestimate and Either 35 or $25 \mu \mathrm{g}$ of Ethinyl Estradiol," Contraception, Vol. 76, No. 1, 2007, pp. 8-17. doi:10.1016/j.contraception.2007.04.002

[26] S. Abraham, G. Luscombe and I. Soo, "Oral Contraception and Cyclic Changes in Premenstrual and Menstrual Experiences," Journal of Psychosomatic Obstetrics \& Gynecology, Vol. 24, No. 3, 2003, pp. 185-193. doi:10.3109/01674820309039672

[27] C. Rothenberg, et al., "The Rise and Fall of Estrogen Therapy: The History of HRT," Harvard Law, 2005.

[28] A. Yildiz, et al., "Protein Kinase C Inhibition in the Treat- ment of Mania," Archives of General Psychiatry, Vol. 65, No. 3, 2008, pp. 255-263.

doi:10.1001/archgenpsychiatry.2007.43

[29] C. Zarate, et al., "Efficacy of a Protein Kinase C Inhibitor (Tamoxifen) in the Treatment of Acute Mania: A Pilot Study," Bipolar Disorders, Vol. 9, No. 6, 2007, pp. 561570. doi:10.1111/j.1399-5618.2007.00530.x

[30] J. Kulkarni, K. Garland, A. Scaffidi, B. Headey, R. Anderson, A. De Castella, P. Fitzgerald and S. Davis, "A Pilot Study of Hormone Modulation as a New Treatment for Mania in Women with Bipolar Affective Disorder," Psychoneuroendocrinology, Vol. 31, No. 4, 2005, pp. 543547. doi:10.1016/j.psyneuen.2005.11.001

[31] J. Bebchuck, et al., "A Preliminary Investigation of a Protein Kinase C Inhibitor in the Treatment of Acute Mania," Archives of General Psychiatry, Vol. 57, No. 1, 2000, pp. 95-97. doi:10.1001/archpsyc.57.1.95

[32] R. Zanardi, et al., "Response to SSRIs and Role of the Hormonal Therapy in Post-Menopausal Depression," European Neuropsychopharmacology, Vol. 17, 2006, pp. 400-405. doi:10.1016/i.euroneuro.2006.11.001

[33] G. Chouinard, et al., "Estrogen-Progesterone Combination: Another Mood Stabilizer?" American Journal of Psychiatry, Vol. 144, No. 6, 1987, p. 826.

[34] M. Huang, Y. Wang and C. Chan, "Estrogen-Progesterone Combination for Treatment-Refractory Post-Partum Mania," Psychiatry and Clinical Neurosciences, Vol. 62, No. 1, 2008, p. 126. doi:10.1111/j.1440-1819.2007.01782.x

[35] N. Rasgon, M. Bauer, T. Glenn, S. Elman and P. Whybrow, "Menstrual Cycle Related Mood Changes in Women with Bipolar Disorder," Bipolar Disorders, Vol. 5, No. 1, 2003, pp. 48-52. doi:10.1034/j.1399-5618.2003.00010.x

[36] Z. Amin, et al., "Effect of Estrogen-Serotonin Interactions on Mood and Cognition," Behavioral and Cognitive Neuroscience Reviews, Vol. 4, No. 1, 2005, pp. 43-58. doi: $10.1177 / 1534582305277152$

[37] P. Sabioni, et al., "The Anti-Manic-Like Effect of Tamoxifen: Behavioural Comparison with Other PKC-Inhibiting and Antiestrogenic Drugs," Progress in NeuroPsychopharmacology and Biological Psychiatry, Vol. 32, No. 8, 2008, pp. 1927-1931.

doi:10.1016/j.pnpbp.2008.09.023

[38] M. Hardoy, et al., "Increased Neuroactive Steroid Concentrations in Women with Bipolar Disorder or Major Depressive Disorder," Journal of Clinical Psychopharmacology, Vol. 26, No. 4, 2006, pp. 379-384. doi:10.1097/01.jcp.0000229483.52955.ec

[39] G. Kaur, et al., "Evidence for Serotonergic Modulation of Progesterone-Induced Hyperphagia, Depression and Algesia in Female Mice," Brain Research, Vol. 943, No. 2, 2002, pp. 206-215. doi:10.1016/S0006-8993(02)02624-0

[40] A. Wihlback, et al., "Influence of Postmenopausal Hormone Replacement Therapy on Platelet Serotonin Uptake Site and Serotonin2A Receptor Binding," American College of Obstetricians and Gynecologists, Vol. 98, No. 3, 2001, pp. 450-457. 
[41] R. Hiroi, et al., "Estrogen Selectively Increases Tryptophan Hydroxylase-2 mRNA Expression in Distinct Subregions of Rat Midbrain Raphe Nucleus: Association between Gene Expression and Anxiety Behavior in the Open Field," Biological Psychiatry, Vol. 60, No. 3, 2006, pp. 288-295.

[42] N. Pluchino, et al., "Progesterone and Brain: An Update," Maturitas, Vol. 62, No. 4, 2009, pp. 349-355. doi:10.1016/j.maturitas.2008.11.023

[43] A. Khan, "Menopause Manifesting as Bipolar Symptoms," Journal of Psychiatric Practice, Vol. 13, No. 5, 2007, pp. 339-342. doi:10.1097/01.pra.0000290674.76041.da

[44] Z. Amin, et al., "Effect of Estrogen-Serotonin Interactions on Mood and Cognition," Behavioral and Cognitive Neuroscience Reviews, Vol. 4, No. 1, pp. 43-58, 2005. doi:10.1177/1534582305277152

[45] G. Sullivan, "Positron Emission Tomography Quantification of Serotonin-1A Receptor Binding in MedicationFree Bipolar Depression," Biological Psychiatry, Vol. 66, No. 3, 2009, pp. 223-230. doi:10.1016/i.biopsych.2009.01.028

[46] N. Kurshan, et al., "Oral Contraceptives and Mood in Women with and without Premenstrual Dysphoria: A Theoretical Model," Archives of Women's Mental Health, Vol. 9, No. 1, 2006, pp. 1-14. doi:10.1007/s00737-005-0102-Z

[47] National Cancer Institute UNIoH, "Tamoxifen: Questions and Answers," 2010.

http://wwwcancergov/cancertopics/factsheet/Therapy/tam oxifen

[48] C. Shen, et al., "Comment to Dr. Yatham Regarding Tamoxifen Listed as a Third-Line Recommendation for the Pharmacological Treatment of Acute Mania," Bipolar Disorders, Vol. 11, No. 7, 2009, pp. 773-775.

[49] R. Love, et al., "Effects of Tamoxifen on Bone Mineral Density in Post-Menopausal Women with Breast Cancer," The New England Journal of Medicine, Vol. 326, No. 13, 1992, pp. 852-856. doi:10.1056/NEJM199203263261302

[50] C. Kelly, "Selective Serotonin Reuptake Inhibitors and Breast Cancer Mortality in Women Receiving Tamoxifen: A Population Based Cohort Study," British Medicine Journal, Vol. 340, No. 693, 2010, pp. 1-8.

[51] T. Lash, et al., "Tamoxifen's Protection against Breast Cancer Recurrence Is Not Reduced by Concurrent Use of the SSRI Citalopram," British Journal of Cancer, Vol. 99, No. 4, 2008, pp. 616-621.

[52] S. Goel, et al., "Effect of Anti-Estrogens on MES and Their Interaction with Antiepileptics in Wistar Rats," Pharmacology Online, Vol. 1, 2009.

[53] M. Pasquini, et al., "Quetiapine for Tamoxifen-Induced Insomnia in Women with Breast Cancer," Psychosomatics, Vol. 50, No. 2, 2009, pp. 159-161. doi:10.1176/appi.psy.50.2.159

[54] C. Yde, et al., "The Antipsychotic Drug Chlorpromazine Enhances the Cytotoxic Effect of Tamoxifen in Tamoxifen-Sensitive and Tamoxifen-Resistant Human Breast Cancer Cells," Anti-Cancer Drugs, Vol. 20, No. 8, 2009, pp. 723-735. doi:10.1097/CAD.0b013e32832ec041
[55] M. Canonico, et al., "Postmenopausal Hormone Therapy and Risk of Idiopathic Venous Thromboembolism: Results from the E3N Cohort Study," Arteriosclerosis, Thrombosis and Vascular Biology, Vol. 30, No. 2, pp. 340-345. doi:10.1161/ATVBAHA.109.196022

[56] S. Toh, et al., "Coronary Heart Disease in Postmenopausal Recipients of Estrogen plus Progestin Therapy: Does the Increased Risk Ever Disappear?" Annals of Internal Medicine, Vol. 152, No. 4, 2010, pp. 211-217.

[57] C. Harden, et al., "Hormone Replacement Therapy in Women with Epilepsy: A Randomized, Double-Blind, Placebo-Controlled Study," Epilepsia, Vol. 47, No. 9, 2006, pp. 1447-1451. doi:10.1111/j.1528-1167.2006.00507.x

[58] C. Harden, "Hormone replacement therapy: Will It Affect Seizure Control and AED Levels?" Seizure, Vol. 17, No. 2, 2008, pp. 176-180. doi:10.1016/j.seizure.2007.11.026

[59] V. Gabbay, M. A. O’Dowd, M. Mamamtavrishvili and G. M. Asnis, "Clozapine and Oral Contraceptives: A Possible Drug Interaction," Journal of Clinical Psychopharmacology, Vol. 22, No. 6, 2002, pp. 621-622. doi:10.1097/00004714-200212000-00013

[60] M. Rosenberg, "Efficacy, Cycle Control, and Side Effects of Low- and Lower-Dose Oral Contraceptives: A Randomized Trial of $20 \mathrm{mg}$ and $35 \mathrm{mg}$ Estrogen Preparations," Contraception, Vol. 60, 2000, pp. 321-329. doi:10.1016/S0010-7824(99)00109-2

[61] M. D. O'Brien and J. Guillebaud, "Contraception for Women with Epilepsy,” Epilepsia, Vol. 47, No. 9, 2006, pp. 1419-1422. doi:10.1111/j.1528-1167.2006.00671.x

[62] A. Sonnen, "Sodium Valproate and the Pill," In: H. Akimoto, H. Kazamatsun and M. Seino, Eds., Advances in Epileptology, Raven Press, New York, 1982, pp. 429-432.

[63] P. Crawford, D. Chadwick and P. Cleland, "The Lack of Effect of Sodium Valproate on the Pharmacokinetics of Oral Contraceptive Steroids," Contraception, Vol. 33, No. 1, 1986, pp. 23-29. doi:10.1016/0010-7824(86)90028-4

[64] J. Sidhu, S. Job, S. Singh and R. Philipson, "The pharmacokinetic and Pharmacodynamic Consequences of the Co-Administration of Lamotrigine and a Combined Oral Contraceptive in Healthy Female Subjects," British Journal of Clinical Pharmacology, Vol. 61, No. 2, 2006, pp. 191-199. doi:10.1111/j.1365-2125.2005.02539.x

[65] C. Fattore, G. Cipolla and G. Gatti, "Induction of Ethinylestradiol and Levonorgestrel Metabolism by Oxcarbazepine in Healthy Women," Epilepsia, Vol. 40, No. 6, 1999, pp. 783-787. doi:10.1111/j.1528-1157.1999.tb00779.x

[66] J. P. Klosterskov, V. Saano, P. Haring, B. Svenstrup and G. Menge, "Possible Interaction between Oxcarbazepine and an Oral Contraceptive," Epilepsia, Vol. 33, No. 6, 1992, pp. 1149-1152. doi:10.1111/j.1528-1157.1992.tb01773.x

[67] W. Rosenfeld, D. Doose and S. Walker, "Effects of Topiramate on the Pharmacokinetics of an Oral Contraceptive Containing Norethindrone and Ethinyl Estradiol in Patients with Epilepsy," Epilepsia, Vol. 38, No. 3, 1997, pp. 317-323. doi:10.1111/j.1528-1157.1997.tb01123.x

[68] J. Christensen, V. Petrenaite, J. Atterman, P. Sidenius, I. Öhman, T. Tomson and A. Sabers, "Oral Contraceptives Induce Lamotrigine Metabolism: Evidence from a Dou- 
ble-Blind, Placebo-Controlled Trial,” Epilepsia, Vol. 48, No. 3, 2007, pp. 484-489.

doi:10.1111/j.1528-1167.2007.00997.x

[69] K. Browning, A. Bimbaum, J. Montgomery and M. Newman, "Lamotrigine Clearance Is Increased by EstrogenContaining Oral Contraceptives," Neurology, Vol. 66, No. 2, 2006, p. 73.

[70] A. Sabers, I. Ohman, J. Christensen and T. Tomson, "Oral Contraceptives Reduce Lamotrigine Plasma Levels," Neurology, Vol. 61, No. 3, 2003, pp. 570-571.

[71] A. Reimers, G. Helde and E. Brodtkorb, "Ethinyl Estradiol, Not Progestogens, Reduces Lamotrigine Serum Concentrations," Epilepsia, Vol. 46, No. 9, 2005, pp. 14141417. doi:10.1111/j.1528-1167.2005.10105.x

[72] L. N. Yatham, S. H. Kennedy, C .O'Donovan, S. V. Parikh, G. MacQueen, R. S. McIntyre, V. Sharma and S. Beaulieu, "Canadian Network for Mood and Anxiety Treatments (CANMAT) Guidelines for the Management of Patients with Bipolar Disorder: Update 2007," Bipolar Disorders, Vol. 8, No. 6, 2006, pp. 721-739. doi:10.1111/j.1399-5618.2006.00432.x

[73] B. Segebladh, et al., "Prevalence of Psychiatric Disorders and Premenstrual Dysphoric Symptoms in Patients with Experience of Adverse Mood during Treatment with Combined Oral Contraceptives," Contraception, Vol. 79, No. 1, 2009, pp. 50-55. doi:10.1016/j.contraception.2008.08.001

[74] K. Yonkers, et al., "Efficacy of a New Low-Dose Oral Contraceptive with Drospirenone in Premenstrual Dysphoric Disorder," Obstetrics and Gynecology, Vol. 106, No. 3, 2005, pp. 492-501. doi:10.1097/01.AOG.0000175834.77215.2e

[75] K. Oinonen and D. Mazmanian, "Effects of Oral Contraceptives on Daily Self-Ratings of Positive and Negative Affect," Journal of Psychosomatic Research, Vol. 51, No. 5, 2001, pp. 647-658. doi:10.1016/S0022-3999(01)00240-9

[76] J. Payne, et al., "Premenstrual Mood Symptoms: Study of Familiality and Personality Correlates in Mood Disorder Pedigrees," Archives of Women's Mental Health, Vol. 12, No. 1, 2009, pp. 27-34. doi:10.1007/s00737-008-0043-4

[77] E. Freeman, et al., "Evaluation of a Unique Oral Contraceptive in the Treatment of Premenstrual Dysphoric Disorder," Journal of Women's Health and Gender-Based Medicine, Vol. 10, No. 6, 2001, pp. 561-569. doi:10.1089/15246090152543148

[78] A. Borgstrom, et al., "Adverse Mood Effects of Combined Oral Contraceptives in Relation to Personality Traits," European Journal of Obstetrics and Gynecology and Reproductive Biology, Vol. 141, No. 2, 2008, pp. 127-130. doi:10.1016/j.ejogrb.2008.07.018 